\title{
Conjuring Fascinating Stories: the Case of Sir Arthur Tange
}

\section{Peter Edwards}

Shortly after Frank Crowley, then lecturing in history at the University of Western Australia, started his biography of John Forrest, he confronted his second-year students with a question: 'It is said that every historian should tackle a biography at some stage in his life. What do you think?' As I recall, the second-year students sat there with their mouths opening and closing silently like dyspeptic goldfish. One of them, however, for some reason remembered that remark. Thirty years later I recalled it when I was trying to work out what my next project should be, having just worked on the official history of Australia's involvement in Malaya, Borneo and Vietnam, as well as various other projects. I wanted to do something which built on that work but which was also different. I thought that tackling a biography would be of interest. It occurred to me that somebody really ought to do a biography of the public servant Arthur Tange, a person to whom many historians, myself included, had referred with a one-word summary, either 'legendary' or 'formidable'.

Arthur Tange was a lifelong public servant. Public service to him was more than a career; it was, I think, a vocation. He had the unusual experience of being what was called a First Division officer for more than a quarter of a century eleven years as the Secretary of the Department of External Affairs (1954-65); a diplomatic appointment as High Commissioner to India and Ambassador to Nepal (1965-70); and then 91/2 years as Secretary of the Department of Defence (1970-79).

So, after various negotiations, I am now writing a biography. I am also editing a memoir that Tange himself wrote late in his life, mostly focused on his period in Defence. There is a third part to the project as well. I organised and prepared a list of his papers for the National Library. So, if you now go, as I hope many of you will, to consult MS9847 in the Manuscripts Collection, you will be reading a different sort of publication of mine.

Political scientists these days, we have been told, talk a lot about triangulation. Historians like to talk about memory — how do we construct memory and what is the interaction between individual memory and collective memory. So there is a certain dimension in that conversation to be gained from simultaneously ordering the remarkably chaotic and disorganised papers of a bureaucrat; looking at what he wrote about himself; and writing his biography. 
Why write about a senior bureaucrat? It seems to me fairly straightforward. Tange's career peaked in a particular period, between two major revolutions in the public service and the way the public service operated. This first occurred during the Second World War, the second started under the Whitlam Government, with sequels under the Hawke and Keating governments. That period, roughly the 1940s to the 1970s, was the era of the great 'mandarins' of the public service. It is no coincidence that it was also the time of great institution-building in government, the development of major public service departments.

I have conjured up a rather fanciful image of how policy was actually formed on major issues during that time, and particularly during the long Menzies period. One can compare, I think, Menzies with a sort of medieval monarch in his court, surrounded by various barons, they being the major ministers and also the major heads of department, with certain fluctuating coalitions and combinations forming. And what formed a really powerful combination was if there was a politically powerful minister with a powerful, bureaucratically astute public servant at the head of his department. The classic example would be John McEwen and John Crawford as respectively Minister and Secretary of the Department of Trade.

In writing the biography there have been various stakeholders whose interests I have to consider and balance. There is firstly the subject himself. I have had an unusual experience concerning the question of whether to write on a living or deceased subject. Arthur Tange was alive when I started work and he is now dead. But his son and daughter are very much alive, and I have had to consider that. The project has also been supported by the Department of Defence. That department and the Department of Foreign Affairs and Trade are, despite their reputations for secrecy and a consciousness of security, among the most generous and liberal sponsors of histories. That includes, not just their own history (such as David Day has done for Customs), but also histories of topics within their general field. It is something that other public service departments might do well to follow.

I like asking political science-type questions. Many of my interests are to do with the interaction of institutions and individuals and how power is gained, how power is exercised, how policy is made. I have tried to combine those interests into something of interest to that mythical character, beloved of publishers, the 'interested general reader'.

The four major themes are nicely alliterative: policy, politics, public administration and personality. I simply do not think one can understand how major policy decisions in this period emerge without understanding the interaction between ministers and senior public servants at this time. Pat Weller made the comment some time ago that if the mandarins wanted to claim the 
credit for all the things that went right in that period, they had to take some of the blame for what went wrong. It is a fair comment. My response would be that, in many cases, what we now see as successful examples of policy-making and policy creation were cases when ministers and their top public servants worked very effectively together, each knowing and understanding what the other could and could not do. In the period that I am dealing with, the cases included the negotiation of the ANZUS Treaty and the Colombo Plan, the handling of Indonesian confrontation in the 1960s, and the reorganisation of strategic policy in the 1970s. On the other hand, what we now generally see as policy failures, such as the 1956 Suez crisis, or the discussions that led to Australian involvement in Vietnam in 1965, were cases where there was a disjunction between the top level public servants and the ministers. There was distrust, there was sidelining, there was exclusion, there was simply not the collaboration that marks good minister-official relations.

Politics in the sense that we often use that term, the sort of stuff that feeds the headlines of the newspapers, does not figure prominently in this account. Public servants themselves are not supposed to be involved in that sort of thing. It does so happen, however, that Tange was a little more involved than he wished, albeit unwittingly, in the downfall of John Gorton as prime minister. There is also the theory, repeatedly alleged by certain journalists in the 1970s and 1980s, that Arthur Tange was the evil genius who was the link between the security crisis and the constitutional crisis in late 1975. According to this story, Tange was the person who told Sir John Kerr that the CIA was worried about the Whitlam Government, thus contributing substantially to the dismissal. I have taken that story out of the main body of my narrative. An appendix in the book discusses what Tange did or did not do in 1975 on the security crisis, the constitutional crisis and the third largely simultaneous crisis, the covert Indonesian invasion of East Timor leading to the death of five Australia-based journalists at Balibo.

There is a close relationship between policy structures, policy-making structures and policy outcomes. That would seem to be fairly straightforward, although it is a little subtler than the familiar American political science dictum, 'where you stand depends upon where you sit'. I interviewed, among many other people, Gough Whitlam or, as he preferred to say, he granted me an audience. Soon after that experience, I pressed the button on my telephone answering machine. That very familiar voice emerged: 'The trouble with you, Peter, is you take the departmental view'. It was not meant as a compliment but I in fact took it as one because I took it as confirmation that there is such a thing as the 'departmental view'. Tange's achievement in developing a professional foreign office and diplomatic service out of what had been a rather disparate bunch of more or less talented individuals led to the creation of something that could be called a 'departmental line' in foreign policy. This was different from either the standard party line of either the Coalition parties or the Labor Party. The interaction of 
these various lines is what has led to some of our most interesting policy decisions.

Tange is best remembered now for the so-called Tange reforms of Defence in the 1970s, when five departments were merged into one. This not only raised many issues about civil-military relations and the merger of three services into one Australian Defence Force. It is also closely related to the strategic policies associated with phrases like 'self-reliance' and 'the defence of Australia', concepts now coming under serious challenge for the first time.

It is impossible to talk of Tange without discussing his personality. Stories about Tange in his day were legion throughout Canberra and the public service, especially stories of his confrontations with public servants, throwing files down in front of them so the unfortunate officer would have to scramble on the floor to pick up the disarrayed papers. There were his telephone conversations where, as he sometimes said, 'I have to strike like lightning'. What I want to discuss is the effect that his personality had on the operations of his departments. Did it help to generate good policy discussion or did it constrict policy-making?

To bring these themes together, I have structured the book around the theme of the relationship between ministers and mandarins. The most interesting question, from this period of great mandarins, is what made for good, productive relationships between a minister and the head of department and what made for dysfunctional relationships. Tange, as he liked to claim, was very proud of having directly served 17 ministers and five prime ministers. So he had the full range of experience, from one that was almost a filial, father-son relationship to one verging on open hostility. What was it that made for good relationships, what was it that did not?

It does occur to me that somebody might like to make one of those docu-dramas of the relationship between Tange and Hasluck from their days as undergraduates at UWA in the 1930s through to the 1980s as retired gentlemen, full of years and honours. It would make a fascinating story. I am sure that if Geoffrey Bolton (Hasluck's latest biographer) and I were consultants on such an episode, we would collaborate rather better than Tange and Hasluck did in 1965.

This biography has taken me into a variety of areas, in order to discuss Tange's public and private life. I necessarily discuss matters such as income and family life, including his relations with his children. There is not as much about his sex life as might be expected by a culture obsessed with who is sleeping with whom, but I do not think that is a huge weakness. I do have to touch on numerous historical fields, other than foreign and defence policy. One is immigration history, since one side of his forebears came from Denmark and the other from Britain, in fact the Anglo-Irish Ascendancy. One gets into sports history, because the different roles of rugby union in New South Wales and in Western Australia come into this story. One gets into economic history and 
banking history, because an early mentor of Tange's, a relation by marriage, was Sir Alfred Davidson, the influential head of the Bank of New South Wales in the 1930s and 1940s. One touches on a matter raised earlier in this workshop, concerning the development of a common ethos among international civil servants, particularly around the late 1940s. The first air trip that Arthur Tange ever made - he never liked air trips very much — was in a DC4 flying over the Pacific during wartime to a little-known place in New Hampshire called Bretton Woods.

In this biography I have tried to bring together these themes, to answer questions in a way that I hope will be not only useful to political scientists, not least those in this room, but also of interest to many other Australians. If you will forgive the cliché, there is a fascinating Australian story behind it all. 